\title{
Physicochemical and Phytochemical Analysis of Different Parts of Indian Kesar Mango-A unique variety from Saurashtra Region of Gujarat
}

\author{
Kalpna Rakholiya*, Mital Kaneria and Sumitra Chanda \\ Department of Biosciences, Saurashtra University, Rajkot-360 005, Gujarat, INDIA.
}

\begin{abstract}
The aim of the present study was to evaluate physicochemical and phytochemical analysis of different parts (ripe seed, unripe seed, ripe peel, unripe peel and stem) of Indian mango (var. 'Kesar') collected from Saurashtra region of Gujarat. The physiochemical properties such as loss on drying, total ash value, acid insoluble ash value, water soluble ash value and extractive values were carried out. The phytochemical properties such as alkaloids, flavonoids, tannins, phlobatanins, triterpenes, steroids, saponins and cardiac glycosides were also carried out. In phytochemical analysis, tannins showed maximum amounts in all five parts. The present study provides the details physicochemical and phytochemical properties of different parts of kesar mango which are useful in laying down standardization
\end{abstract}

and pharmacopeia parameters

Key words: Kesar Mango, Physicochemical parameters, Phytochemical analysis, Ripe and Unripe Peel, Ripe and Unripe Seeds, Stem.

Corresponding author: Kalpna Rakholiya, Phytochemical, Pharmacological and Microbiological Laboratory, Department of Biosciences, Saurashtra University, Rajkot-360 005, Gujarat, INDIA.

Tel: 9726599451

Email: kalpna.rakholiya@gmail.com

DOI : $10.5530 /$ pj.2016.5.16

\section{INTRODUCTION}

The plant kingdom has been the safeguard for the survival of the humans throughout recorded history. Plants have been the basis of many traditional medicine systems throughout the world for thousands of years and continue to provide mankind with new remedies. The research on plants of medicinal importance is rapidly increasing at National and International level. ${ }^{1-3}$ Use of plants as a source of medicine has been inherited and is an important component of the health care system in India.

In the Indian systems of medicine, most practitioners formulate and dispense their own recipes; hence this requires proper documentation and research. In western world also, the use of herbal medicines is steadily growing with approximately $40 \%$ of population use herbs to treat medical illnesses. $^{4,5}$ Public, academic and government interest in traditional medicines is growing exponentially due to the increased incidence of the adverse drug reactions and economic burden of the modern system of medicine. ${ }^{6}$ The Charaka Samhita (1000 B.C.) mentions the use of over 2000 herbs for medicinal purposes. ${ }^{7}$ It has continued to be used not only for primary health care of the poor in developing countries, but also in countries where conventional medicine is predominant in the national health care system.

The medicinal properties of plants are due to some chemical substances that produce certain definite physiological action on the human body. These non-nutritive components are called phytochemicals. The qualitative analysis as well as quantification of phytochemicals of a medicinal plant is regarded as vital step in any kind of medicinal plant research. Mango (Mangifera indica L.) belonging to the family Anacardiaceae, is one of the major fruit crops in India. Besides fruit yielding, this plant is used for various other therapeutically purposes. Present study was conducted on physicochemical and phytochemical analysis on the different parts of the local variety 'Kesar' of the Mango (Mangifera indica L.). According to previous published data in same plant parts, exhibited a considerably high antimicrobial activity against the tested pathogenic microorganisms as well as better antioxidant activity as compared that of the standard. ${ }^{8-11}$ This biological activity due to the presence of phytochemical in mango plant.Thereforethe present study is to analyses physicochemical parameters and preliminary phytochemical investigation to characterize the plant material. In our study, Kesar variety was selected because uniqueness of Gir kesar mango is due to colour, taste of pulp is sweet and fibreless and produce special aroma are unique and popular in Saurashtra region of Gujarat, India. To the best of our knowledge phytochemical and physicochemical analysis of different parts of mango (var. Kesar) have never been comparatively evaluated in this variety.

\section{MATERIAL AND METHODS}

\section{Collection of plant material}

Mangifera indica L. var. Kesar fruits and stem were collected from Saurashtra region, Gujarat, India in the month of May 2010. The plant was compared with voucher specimen (Voucher speciment No. SU/ BIO/514/Thakrar) deposited at Department of Biosciences, Saurashtra University, Rajkot, Gujarat, India. The parts were separated, washed thoroughly with tap water, shade dried, homogenized to fine powder and stored in air tight bottles.

\section{Chemicals, reagents and solvents}

All chemicals, reagents and solvents used during the experimentation were of analytical grade.

\section{Physicochemical study \\ Determination of loss on drying}

Two grams of crude powder was taken in an evaporating dish and then dried in an oven at $105^{\circ} \mathrm{C}$ till constant weight was obtained. The weight after drying was noted and loss on drying was calculated. The percentage was calculated on the basis of sample taken initially. ${ }^{12}$ 


\section{Determination of total ash}

Two grams of dry powder was taken in a silica crucible and heated gradually increasing the heat to $500^{\circ} \mathrm{C}$ until it was white, indicating the absence of carbon. Ash was cooled in a desiccator and weighed without delay. Total ash value was calculated as $\mathrm{mg} \mathrm{g}^{-1}$ of air-dried material. ${ }^{12}$

\section{Determination of water soluble ash}

To the crucible containing the total ash, $25 \mathrm{ml}$ of water was added and boiled for $5 \mathrm{~min}$. The insoluble matter was collected on an ash less filter paper. It was washed with hot water and heated in a crucible for $15 \mathrm{~min}$. Weight of insoluble matter was subtracted from the weight of total ash. The content of water soluble ash was calculated in $\mathrm{mg} \mathrm{g}^{-1}$ of air dried material. $^{12}$

\section{Determination of acid insoluble ash}

Twenty five ml of hydrochloric acid $\left(70 \mathrm{gL}^{-1}\right)$ was added to the crucible containing total ash. It was covered with a watch-glass and heated gently for 5 min to boil. The watch-glass was rinsed with $5 \mathrm{ml}$ of hot water and this liquid was added to the crucible. The insoluble matter was collected on an ash less filter paper and it was washed with hot water until the filter was neutral. The filter paper containing the insoluble matter was transferred to the original crucible; it was dried on a hot plate and heated till constant weight was obtained. The residue was allowed to cool in desiccators for 30 minutes and then weighed without delay. Acid insoluble ash was calculated in $\mathrm{mg} \mathrm{g}^{-1}$ of air dried material. ${ }^{12}$

\section{Determination of petroleum ether soluble extractive value}

Five grams of dried powder was taken in $100 \mathrm{ml}$ of petroleum ether in a conical flask, plugged with cotton wool and then kept on a rotary shaker at $120 \mathrm{rpm}$ for $24 \mathrm{~h}$. Thereafter, it was filtered and the filtrate was evaporated to dryness at $105^{\circ} \mathrm{C}$ till constant weight was obtained. The percentage of extractable matter was calculated with reference to the sample taken initially. ${ }^{12}$

\section{Determination of methanol soluble extractive value}

Five grams of dried powder was taken in $100 \mathrm{ml}$ of methanol in a conical flask, plugged with cotton wool and then kept on a rotary shaker at $120 \mathrm{rpm}$ for $24 \mathrm{~h}$. Thereafter, it was filtered and the filtrate was evaporated to dryness at $105^{\circ} \mathrm{C}$ till constant weight was obtained. The percentage of extractable matter was calculated with reference to the sample taken initially. ${ }^{12}$

\section{Determination of acetone soluble extractive value}

Five grams of dried powder was taken in $100 \mathrm{ml}$ of acetone in a conical flask, plugged with cotton wool and then kept on a rotary shaker at $120 \mathrm{rpm}$ for $24 \mathrm{~h}$. Thereafter, it was filtered and the filtrate was evaporated to dryness at $105^{\circ} \mathrm{C}$ till constant weight was obtained. The percentage of extractable matter was calculated with reference to the sample taken initially. ${ }^{12}$

\section{Determination of water soluble extractive value}

Five grams of dried powder was taken in $100 \mathrm{ml}$ of water in a conical flask, plugged with cotton wool and then kept on a rotary shaker at $120 \mathrm{rpm}$ for $24 \mathrm{~h}$. Thereafter, it was filtered and the filtrate was evaporated to dryness at $105^{\circ} \mathrm{C}$ till constant weight was obtained. The percentage of extractable matter was calculated with reference to the sample taken initially. ${ }^{12}$

\section{Qualitative phytochemical analysis}

The crude powder of different parts was subjected to qualitative phytochemical analysis. ${ }^{13-15}$

\section{Alkaloids}

The crude powder was dissolved in $2 \mathrm{~N} \mathrm{HCl}$. The mixture was filtered and the filtrate was divided into 3 equal portions. One portion was treated with a few drops of Mayer's reagent; one portion was treated with an equal amount of Dragondroff reagent and the other portion was treated with an equal amount of Wagner's reagent. The creamish precipitate, orange precipitate and brown precipitate indicated the presence of respective alkaloids. ${ }^{16}$

\section{Flavonoids}

Alkaline reagent test was performed for checking the presence of flavonoids. The crude powder was treated with a few drops of diluted sodium hydroxide $(\mathrm{NaOH})$ separately. Formation of intense yellow color which turned colorless on addition of a few drops of diluted $\mathrm{HCl}$ indicated the presence of flavonoids.

\section{Tannins}

The crude powder was treated with alcoholic ferric chloride $\left(\mathrm{FeCl}_{3}\right)$ reagent. Blue color indicated the presence of tannins. ${ }^{17}$

\section{Phlobatanins}

The crude powder was boiled with $1 \%$ aqueous $\mathrm{HCl}$. Deposition of red precipitate was taken as evidence of the presence of phlobatanins. ${ }^{13}$

\section{Triterpenes}

Chloroform extract of the crude powder was treated with concentrated sulphuric acid $\left(\mathrm{H}_{2} \mathrm{SO}_{4}\right)$. Appearance of reddish brown ring indicated the presence of triterpenes. ${ }^{13}$

\section{Steroids}

Liebermann-Burchard reaction was performed for checking the presence of steroids. A chloroformic solution of the crude powder was treated with acetic anhydride and a few drops of concentrated $\mathrm{H}_{2} \mathrm{SO}_{4}$ were added down the sides of the test tube. A blue green ring indicated the presence of steroids.

\section{Saponins}

The presence of saponins was determined by Frothing test. The crude powder was vigorously shaken with distilled water and was allowed to stand for $10 \mathrm{~min}$ and classified for saponin content as follows: no froth indicates absence of saponins and stable froth of more than $1.5 \mathrm{~cm}$ indicated the presence of saponins. ${ }^{18}$

\section{Cardiac glycosides}

Keller-kiliani test was performed for checking the presence of cardiac glycosides. The crude powder was treated with $1.0 \mathrm{ml}$ mixture of $5 \%$ $\mathrm{FeCl}_{3}$ and glacial acetic acid $\left(1: 99 \mathrm{v} \mathrm{v}^{-1}\right)$. To this solution, a few drops of concentrated $\mathrm{H}_{2} \mathrm{SO}_{4}$ were added. Appearance of greenish blue colour within few minutes indicated the presence of cardiac glycosides. ${ }^{19}$

\section{Statistical analysis}

Each sample was analyzed individually in triplicate and the results are expressed as the mean value $(n=3) \pm$ Standard Error of Mean (S.E.M.). 


\begin{tabular}{ccccc}
\hline \multicolumn{4}{c}{ Table 1: Physicochemical parameters of different parts of mango. } \\
\hline $\begin{array}{c}\text { Parts } \\
\text { name }\end{array}$ & Loss on drying & Total ash & $\begin{array}{c}\text { Water } \\
\text { soluble ash }\end{array}$ & $\begin{array}{c}\text { Acid } \\
\text { insoluble ash }\end{array}$ \\
\hline Ripe peel & $8.5 \pm 0.00$ & $4.33 \pm 0.60$ & $8.34 \pm 0.29$ & $7.91 \pm 0.29$ \\
Unripe peel & $7.5 \pm 0.00$ & $2.83 \pm 0.17$ & $7.9 \pm 0.54$ & $7.4 \pm 1.60$ \\
Ripe seed & $8.5 \pm 0.00$ & $2.33 \pm 0.17$ & $8.92 \pm 0.42$ & $8.16 \pm 0.93$ \\
Unripe seed & $8.17 \pm 0.44$ & $2.50 \pm 0.76$ & $8.12 \pm 0.25$ & $7.83 \pm 0.60$ \\
Stem & $7.95 \pm 0.29$ & $3.56 \pm 1.25$ & $6.53 \pm 0.54$ & $5.98 \pm 0.23$ \\
\hline
\end{tabular}

Table 2: Qualitative phytochemical analysis of different parts of mango

\begin{tabular}{|c|c|c|c|c|c|c|}
\hline Phytochemicals & Test & Stem & Ripe peel & $\begin{array}{c}\text { Unripe } \\
\text { peel }\end{array}$ & Ripe seed & $\begin{array}{c}\text { Unripe } \\
\text { seed }\end{array}$ \\
\hline \multirow{3}{*}{ Alkaloids } & Dragendroff's test & +++ & +++ & + & - & ++ \\
\hline & Mayer's test & - & - & - & - & - \\
\hline & Wagner's test & +++ & + & + & - & - \\
\hline Flavonoids & Alkaline reagent & ++ & ++ & + & + & + \\
\hline Tannins & $\mathrm{FeCl}_{3}$ test & +++ & +++ & +++ & +++ & +++ \\
\hline Phlobatanins & $\mathrm{HCl}$ test & ++ & ++ & ++ & - & + \\
\hline Triterpenes & $\mathrm{H}_{2} \mathrm{SO}_{4}$ test & ++ & ++ & ++ & +++ & + \\
\hline Steroids & Liebermann-Burchard test & - & - & - & - & - \\
\hline Saponins & Frothing test & - & - & + & - & - \\
\hline Cardiac glycosides & Keller-kilianni test & +++ & - & ++ & - & - \\
\hline
\end{tabular}

-: Absent; +: Less present; ++: Moderate present; +++: High present.

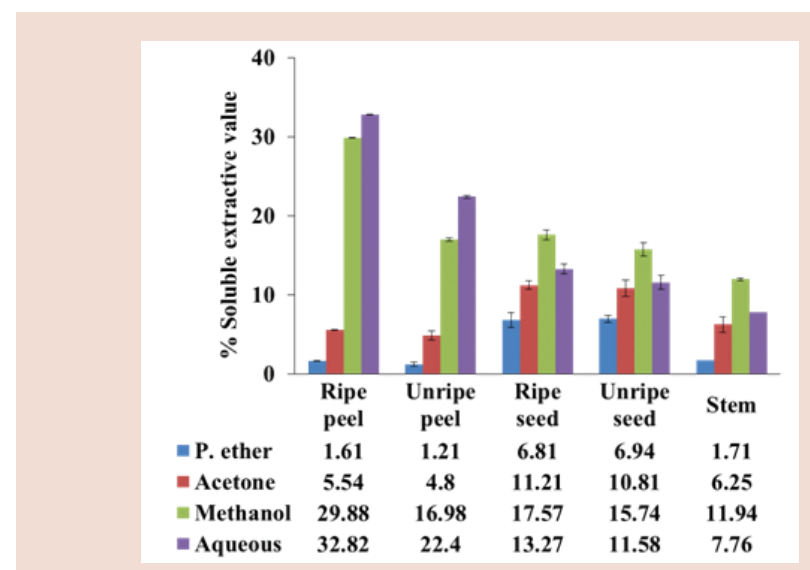

Figure 1: The soluble extractive value of different parts of mango.

\section{RESULTS AND DISCUSSION}

\section{Physicochemical parameters}

The physical constant evaluation of the drugs is an important parameter in detecting adulteration or improper handling of drugs. Physicochemical characterization of powder of studied part is shown in Table 1. The all parts showed less moisture content; it was range from 7.5-8.5\%. Moisture content of drugs could be at minimal level to discourage the growth of bacteria, yeast or fungi during storage. It can serve as a valuable source of information and provide appropriate standards to establish the quality of this plant material in future study or application.

The ash value was determined by three different forms viz., total ash, water soluble ash and acid insoluble ash. The total ash and loss on drying were found in range between $2.33 \%-4.33 \%$ and $7.5-8.5 \%$ respectively while water soluble ash and acid insoluble ash was range from 6.53 $8.92 \%$ and $5.98-8.16 \%$ respectively. Ash values are used to determine quality and purity of crude drug. It indicates presence of various impurities like carbonate, oxalate and silicate. The water soluble ash is used to estimate the amount of inorganic compound present in drugs. The acid insoluble ash measures the amount of silica present; especially sand and it indicate contamination with earthy material. Water soluble ash is the water soluble portion of the total ash. Less amount of these three parameters indicate that the inorganic matter and silica were less in mango parts.

\section{Soluble extractive value}

The extractive value of different parts of mango is shown in Figure 1. The maximum extractive value was found in water solvent minimum was in petroleum ether. In all studied parts soluble extractive values found in rank is petroleum ether $<$ acetone $<$ methanol $<$ aqueous. The extractive values are useful to evaluate the chemical constituents present in the crude drug and also help in estimation of specific constituents soluble in a particular solvent. ${ }^{8,20-22}$

\section{Qualitative phytochemical analysis}

Medicinal plants are long being used as remedies for various diseases in human. Phytochemical analysis of plant revealed the presence of constituents which are known to exhibit medicinal as well as action on the human body. ${ }^{23,24}$ Phytochemical analysis shows the presence of many medicinally important secondary metabolite types of phytoconstituents like alkaloids, cardiac glycosides, saponins, triterpenes, which indicates that the plant possesses high profile values and can be used to treat various kinds of diseases. The presence of these secondary metabolites suggests that the plant might be medicinal importance. The results of qualitative 
phytochemical analysis of the crude powder of different parts of mango are shown in Table 2. All parts had maximum tannins while a steroid was absent.

The qualitative phytochemical investigation gave valuable information about the different phytoconstituents present in the plant, which helps the future investigators regarding the selection of the particular extract for further investigation of isolating the active principle. ${ }^{25} \mathrm{And}$ also gave idea about different phytochemicals have been found to possess a wide range of activities, which may help in protection against chronic diseases. For example, alkaloids protect against chronic disease. Tannins protect from different diseases and disorders caused by microbial infections and free radicals. ${ }^{26-28}$ The biological properties of many plants are due to the phenolic compounds present in them. ${ }^{8,11}$ Physicochemical and phytochemical analysis of leaf and pulp werereported in similar mango variety. ${ }^{10,15,29}$

The plants thus find their medicinal values due to the presence of respective phytochemical constituents. The presence of various phytochemicals in the tested plant reveals that this plant may be a good source for production of new drugs for various ailments.

\section{CONCLUSION}

In phytochemical analysis, tannins showed maximum amounts. The present study provides physicochemical and phytochemical details of the five parts of mango which are useful in laying down standardization and pharmacopoeia parameters. As there is no physicochemical and phytochemical work of five parts of mango at a time on comparative record of this traditionally much valued drug, the present work was taken up with a view to lay down standards, which could be useful to establish the authenticity of this medicinally useful plant. Thus, these plants can be used for further studies to find more about their pharmacological benefits and their potential against fighting various ailments and diseases.

\section{ACKNOWLEDGEMENT}

The authors thank Prof. S.P. Singh, Head, Department of Biosciences, Saurashtra University, Rajkot, Gujarat, India for providing for providing excellent research facilities.

\section{CONFLICT OF INTEREST}

Authors declare, there is no conflict of interest.

\section{ABBREVIATIONS USED}

$\mathrm{FeCl}_{3}$ : Ferric chloride; $\mathrm{HCl}$ : Hydrochloric acid; $\mathrm{H}_{2} \mathrm{SO}_{4}$ : Sulphuric acid; $\mathrm{NaOH}$ : Sodium hydroxide.

\section{REFERENCES}

1. Gupta V, Ghaiye P, Bansal P, Shri R. Pharmacopoeial standards and pharmacognostical studies of leaves of Citrus paradisi Var. Duncan. J Pharm Res. 2011;2(2), 140-3

2. Ankad GM, Pai SR, Upadhya VR, Hurkadale PJ, Hegde HV. Pharmacognostic evaluation of Achyranthescoynei: leaf. Eg J Basic Appl Sci. 2015;2(1):25-31.

3. KhozaBS, Dubery IA, Byth-Illing HA, Steenkamp PA, Chimuka L, Madala NE. Optimization of pressurized hot water extraction of flavonoids from Momordica foetida using UHPLC-qTOF-MS and multivariate chemometric approaches. Food Anal Methods. 2016;9:1480-9.

4. Rakholiya K, Kaneria M, Chanda S. Inhibition of microbial pathogens using fruit and vegetable peel extracts. Int J Food Sci Nutr. 2014a;65(6):733-9.

5. Ojiako OA, Chikezie PC, Ogbuji AC. Radical scavenging potentials of single and combinatorial herbal formulations in vitro. J Trad Compl Med. 2016;6:153-9.

6. Prajapati DD, Patel NM, Patel SS, Patel MS, Savadi RV, Akki KS, Mruthunjaya K. Pharmacognostic studies on Actinodaphne hookeri Meissn leaves. J Pharm Res. 2008;1:48-54.

7. Poornima N, Umarajan KM, Babu K. Studies on anatomical and phytochemical analysis of Oxystelma esculentum (L.f.) R.br. Ex Schltes. Bot Res Inter. 2009;2:239-43.

8. Rakholiya K, Kaneria M, Chanda S. Vegetable and fruit peels as a novel source of antioxidants. J Med Plants Res. 2011;5(1):63-71.

9. Rakholiya K, Kaneria M, Desai D, Chanda S.Antimicrobial activity of decoction extracts of residual parts (seed and peels) of Mangifera indica L. var. Kesar against pathogenic and food spoilage microorganism. In: Microbial Pathogens and Strategies for Combating them: Science, Technology and Education. Ed. by Mendez-Vilas, A., Formatex Research Center, Badajoz, Spain. 2013;2:850-856.

10. Rakholiya K, Kaneria M and Chanda S. Mango Pulp: A potential source of natural antioxidant and antimicrobialagents. Book chapter In: Medicinal Plants: Phytochemistry, Pharmacology and Therapeutics Ed. By Gupta, V.K., M/S. Daya Publication House, New Delhi, India, 2014b;3:253-284

11. Rakholiya K, Kaneria M, Chanda S. In vitro assessment of novel antimicrobial from methanol extracts of matured seed kernel and leaf of Mangifera indica $L$. (Kesar Mango) for inhibition of Pseudomonas spp. and their synergistic potential. Am J Drug Disc Dev. 2015;5(1):13-23.

12. WHO. Quality control methods for medicinal plants. Geneva. 2002;28-31.

13. Harborne JB. Phytochemical methods. $2^{\text {nd }}$ Ed. 1973; Chapman \& Hall. London.

14. Parekh J, Chanda, S. In vitro antibacterial activity of the crude methanol extract of Woodfordia fruticosa kurz. flower (Lythraceae). Braz J Microbiol. 2007;38(2):204-7.

15. Rakholiya K, Chanda S. Pharmacognostic, physicochemical and phytochemical investigation of Mangifera indica L. var. Kesar leaf. Asian Pac J Trop Biomed. 2012;2(2):S680-S4.

16. Salehi-Surmaghi MH, AynehchiY, Amin GH and Mahhmoodi Z. Survey of Iranian plants for saponins, alkaloids, flavonoids and tannins IV. J Sc Pharm Tehran Uni. $1992 ; 2: 1-11$

17. Segelman $A B$, Farnsworth $N R$ and Quimby MD. False negative saponins test results induced by the presence of tannins. I Lloydia. 1969:32(1):52-58.

18. Kapoor LD, Singh A, Kapoor SL, Shrivastava SN. Survey of Indian plants for saponins, alkaloids and flavonoids. I. Lloydia. 1969;32:297-304

19. Ajaiyeoba EO. Phytochemical and antibacterial properties of Parkia biglobosa and Parkia bicolor leaf extracts. Afr J Biomed Res. 2002;5(3):125-9.

20. Thomas S, Patil DA, Patil AG, Chandra N. Pharmacognostic evaluation and physicochemical analysis of Averrhoa carambola L. fruit. J Herb Med Toxicol. 2008;2(2):51-54

21. Dave R, Nagani K, Chanda S. Pharmacognostic studies and physicochemical properties of the Polyalthia longifolia var. pendula leaf. Pharmacog $\mathrm{J}$. 2010;2(13):572-6.

22. Kaneria M, Chanda S. Phytochemical and pharmacognostic evaluation of leaves of Psidium guajava L. (Myrtaceae). Pharmacog J. 2011;3(23):41-5.

23. Vaghasiya $Y$, Nair R, Chanda S. Antibacterial and preliminary phytochemica and physico-chemical analysis of Eucalyptus citriodora Hk leaf. Nat Prod Res. 2008;22(9):754-62.

24. Yadav R, Agarwala M. Phytochemical analysis of some medicinal plants. J Phytol $2011 ; 3(12): 10-4$

25. Sampathkumar S, Ramakrishnan N. Pharmacognostic and phytochemical inves tigation of Naringi crenulata (Roxb.) Nicols. stem. Anc Sci Life. 2011;31(1):17-21.

26. Thenmozhi S, Sundaram RS, Kumar JP, Bihari CG. Pharmacognostical and phytochemical investigation on leaves of Vitex trifolia linn. J Pharm Res. 2011;4:1259-62

27. Tuominen A (2013). Defensive strategies in Geranium sylvaticum, Part 2: Roles of water-soluble tannins, flavonoids and phenolic acids against natural enemies. Phytochemistry. 2013;95:408-20.

28. Zarin MA, Wan HY, Isha A, Armania N. Antioxidant, antimicrobial and cytotoxic potential of condensed tannins from Leucaenaleucocephala hybrid-Rendang. Food Sci Human Well. 2016;5(2):65-75.

29. Nagani KV, Kevalia J, Chanda SV. Pharmacognostical and phytochemical evaluation of stem of Cissus quadrangularis L. Int J Pharm Sci Res. 2011;2(11):285662. 
PICTORIAL ABSTRACT

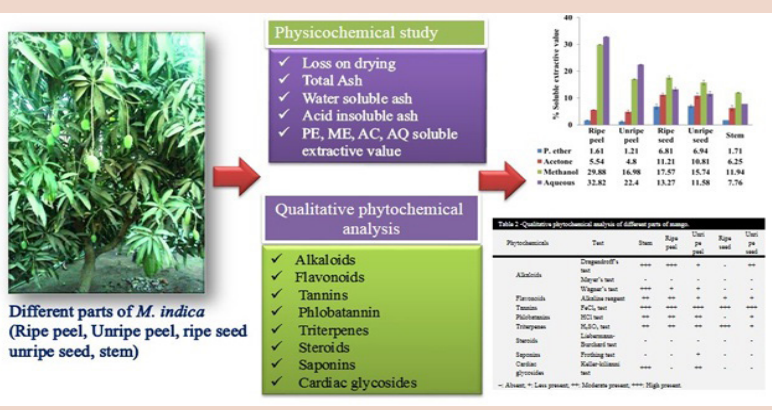

\section{SUMMARY}

- Different parts of kesar mango were selected for the analysis of physicochemical and phytochemical properties.

- Ripe peel shown the maximum extractive values in aqueous followed by methanol.

- Tannins observed maximum in all parts rather than other phytochemicals.

- This study is useful in laying down standardisation and pharmacopeia parameters for kesar mango.

\section{ABOUT AUTHORS}

Kalpna D. Rakholiya: Is a Postdoc fellow at Institute of Biotechnology, Saurashtra University, Rajkot, India. She obtained her M.Sc (2008), M.Phil. (2009) \& Ph.D. (2013) in Microbiology from Department of Biosciences, Saurashtra University, India. Her doctoral research focused on antimicrobial and antioxidant potential of Mango. Currently Dr. K. D. Rakholiya is working on isolation and characterization of halophilic PGPR. 